\title{
MYXOMA OF THE LEFT ATRIUM
}

\author{
BY \\ HAROLD E. ALDRIDGE AND WILLIAM F. GREENWOOD*

\begin{abstract}
From the Department of Medicine, University of Toronto and the Cardiovascular Unit, Toronto General Hospital
\end{abstract}

Received June 9, 1959

Tumours of the heart are not common. Benjamin (1939) reports the incidence of primary tumours as 0.03 per cent of 40,000 autopsies. Nearly 50 per cent of these primary tumours are myxomata or myxomatous polyps. Yater (1931) (77 cases), Mahaim (1945) (82 cases) and Pritchard (1951) (125 cases) have collected and reported cases and the number reported is probably still less than 250. Approximately 75 per cent of myxomata occur in the left atrium, while almost all the remainder are found in the right atrium. Pritchard (1951) records one myxoma arising in the left ventricle and one from the mitral valve. Young and Hunter (1947) also report a left ventricular myxoma.

During the past seven years, from 1951 to April 1958, some 600 operations for the relief of mitral stenosis have been performed at the Toronto General Hospital. Three cases, believed to have mitral stenosis and advised to undergo commissurotomy, were found at operation to have a myxoma of the left atrium. Similar errors in diagnosis have occurred at other centres (Belcher, 1958; Brock, 1956; Chin and Ross, 1957; Fatti and Reid, 1958; Horlick and Merriman, 1957; Likoff et al., 1954). In centres where angiocardiography is used extensively in investigating mitral valve disease, these tumours have been recognized on finding a filling defect of the left atrium (Goldberg et al., 1952; Steinberg et al., 1953; Marions and Ödman, 1957). However, in this centre, if the clinical findings leave doubt as to the presence of mitral stenosis or its dominance in a mixed mitral lesion, left heart catheterization and dye injection studies (Gunton et al., 1958) have been found useful and angiocardiography has not been used. To avoid missing our three cases some 600 angiocardiograms would have been necessary. Routine angiocardiography would not therefore seem a practical solution.

Thus it seems important to review the reported cases to see whether it is possible to distinguish myxomata from mitral stenosis by means other than angiocardiography.

\section{MATERIAL}

Thirty-two case reports have been selected since they contain sufficient details for our purpose (Bahnson et al., 1957, Cases 2 and 3; Belcher, 1958; Bigelow et al., 1955; Block et al., 1932; Brock, 1956; Centano, 1955; Chin and Ross, 1957; Cropper and Winstanley, 1955; Evans, 1956; Fatti and Reid, 1958; Gerbode et al., 1958; Gleason, 1955; Goldberg et al., 1952; Harvey, 1957, Cases 1, 2, 3, 4, and 5; Horlick and Merriman, 1957; Kroopf and Peterson, 1957; Lekisch, 1957; Likoff et al., 1954; Maronde, 1955, Case 2; Martin, 1953; Orr, 1942; Shields, 1956; Steinberg et al., 1953, Cases 1 and 3; Van Buchem and Eerland, 1957; Case records of the Massachusetts' General Hospital, 1957). The following three cases have been added.

\section{CASE REPORTS}

Case 1. A man, aged 46, was admitted to the Toronto General Hospital in 1955 . In 1946 he began to tire more easily. In 1952 he began to be breathless on exertion and developed symptoms and signs of

* Assisted by a National Health Grant at the Ontario Heart Foundation. 
impaired arterial blood supply to the right leg. In 1953 he was in hospital with an afebrile illness, characterized by cough and brownish sputum. During 1954, in spite of digitalis, mercurial diuretics and salt restriction, he became increasingly breathless, so that he could not climb stairs or walk 100 yards without stopping. Oedema, ascites and nocturnal dyspnœa with pink sputum commenced and he was transferred to the Toronto General Hospital for cardiac surgery.

There was no history suggestive of rheumatic fever. He had had a duodenal ulcer with intermittent symptoms for 20 years and at least one episode of melæna and hæmatemesis.

On examination, the patient was sallow, orthopnœic, and looked chronically ill. He was afebrile. There were signs of a small right pleural effusion. The pulse was regular at 80 a minute. There was jugular distension to the angle of the jaw with the patient at $90^{\circ}$. The first sound in the mitral area was loud, and a rumbling diastolic murmur with presystolic accentuation was heard. The second sound in the pulmonary area was also loud. The liver was enlarged and tender and there were moderate ascites and œdema of the feet. The spleen was easily felt. The skin of the right foot was colder than that of the left and the foot required a longer time to return to normal colour after blanching by elevation.

On fluoroscopy there were increased broncho-vascular markings. The left cardiac border was straightened. There was enlargement of the left atrium in the right anterior oblique view. The left ventricle was not enlarged. The right ventricle was prominent. No calcium was seen in the mitral or aortic valve areas. The cardio-thoracic ratio was 45 per cent (m.t.d. $\mathrm{cm}$.).

Electrocardiogram. The rhythm was sinus. There was right axis deviation with depression of the S-T segment due to digitalis. The $P$ waves were not abnormal. Lead $V_{1}$ was not suggestive of right ventricular hypertrophy.

Laboratory Investigation. Urinalysis, normal; blood E.S.R., $18 \mathrm{~mm} . / 1 \mathrm{st}$ hour; $\mathrm{Hb}, 59$ per cent; R.B.C., 5,100,000 per c.mm.; W.B.C., 7000 per c.mm.; non-protein nitrogen, $45 \mathrm{mg}$. per $100 \mathrm{ml}$; W.R., negative; serum proteins and albumen/globulin ratio, normal; cephalin cholesterol flocculation, negative; bromsulphphthalein, 11.8 per cent retention in $45 \mathrm{~min}$.; fæcal benzidine, repeatedly positive.

Mitral stenosis was diagnosed and commissurotomy advised. Before operation the patient was treated for 37 days with a variety of diuretics, digitalis, and a low sodium diet, and the anæmia was corrected, with no improvement in the cardiac status.

Operation was performed under hypothermia, because of chronic heart failure. A large, soft, mushy tumor was found in the left atrium, arising from the inter-atrial wall, and lying on and obstructing the mitral valve. The valve itself was moderately stenosed, admitting the distal interphalangeal joint of the index finger only. It was decided to remove the tumour at a later, planned operation, and finger fracture of the commissure was carried out.

Thirty-six hours after the operation the patient died suddenly.

Autopsy. The heart was enlarged, weighing $500 \mathrm{~g}$. The pericardium was thickened and adherent in places. The right atrium was somewhat dilated and the tricuspid valve was normal. The coronary arteries were normal. The left ventricle was hypertrophied to a maximal thickness of $1.8 \mathrm{~cm}$. The left atrium was dilated. The mitral valve (which had been split) admitted two fingers. The medial cusp was spoonshaped and thickened and the chordæ tendineæ curved upwards and backwards to their myocardial attachments. The posterior valve cusp was normal.

A pyramidal shaped tumor with multiple polypoid prolongations $\left(6 \times 5 \frac{1}{2} \times 1.2 \mathrm{~cm}\right.$.) arose from the postero-medial aspect of the inter-atrial wall some $2 \mathrm{~cm}$. above the mitral valve. The main tumour bulk projected upwards, but a prolongation protruded through the mitral orifice. The tumour had a pinkish, almost gelatinous, appearance. A thickened plaque $(1 \times 0.8 \mathrm{~cm}$.) was present below the left pulmonary vein, probably due to repeated friction by the tumour in systole (Fig. 1). The histology was consistent with the diagnosis of a myxoma (Fig. 2).

The lungs were congested and a small left-sided hæmothorax was present. The liver weighed $2680 \mathrm{~g}$. and the spleen $750 \mathrm{~g}$. Both kidneys were enlarged, right and left weighing 175 and $180 \mathrm{~g}$. respectively. The left renal artery contained tumour cells and the cortex showed ischæmic changes. Further tumour emboli were found in the right popliteal and anterior and posterior tibial arteries.

Case 2 (Bigelow et al., 1955). A woman, aged 50, was admitted to the Toronto General Hospital in 1955. She had noticed palpitations unrelated to effort since 1936. A heart murmur was heard at that time. In 1948 shortness of breath occurred while walking over rough ground, though she was able to walk any distance and carry parcels in town without distress. In 1952 she had several episodes of nocturnal dyspnœa, associated with "rattles" in her chest and mucoid sputum. In 1953 she had an attack of "pneu- 


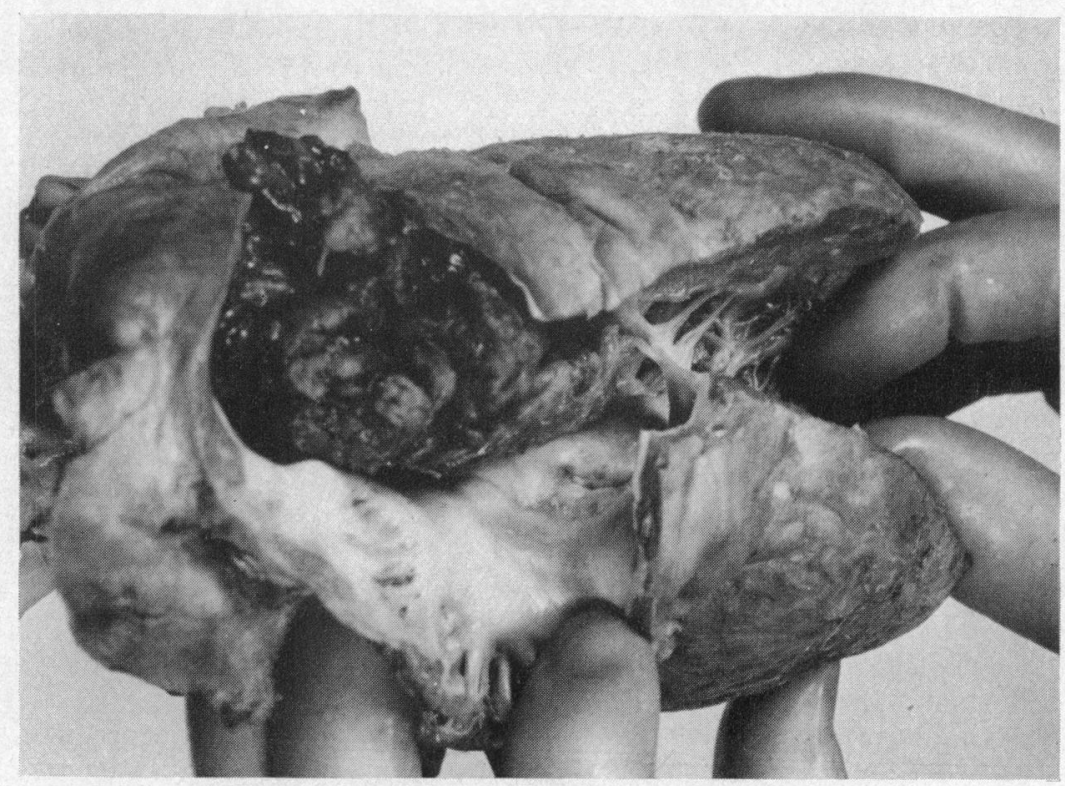

FIG. 1.-Autopsy specimen of a myxoma of the left atrium in situ (Case 1).

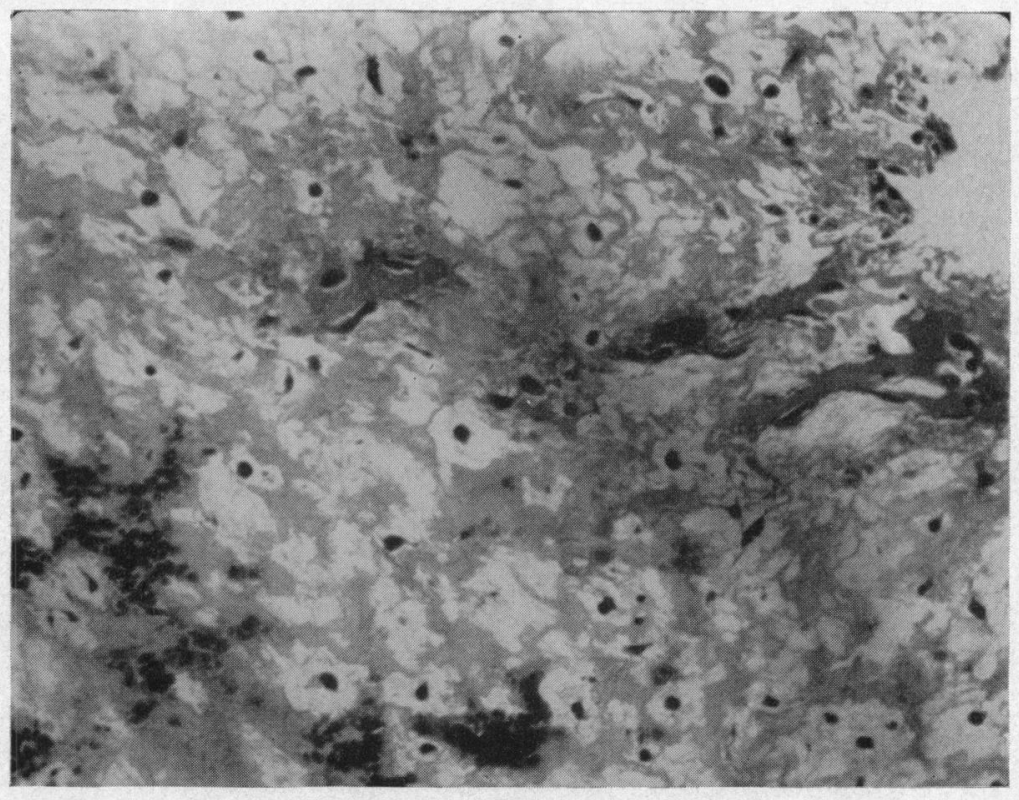

FIG. 2.-Photomicrograph of myxoma (Case 1). Shows part of a papillary tumour formation lined by endothelial cells. There are scattered stellate and spindleshaped cells in a pale eosinophilic staining matrix, which contains thin-walled blood vessels and small areas of hæmorrhage. $\times 144$. Hæmatoxylin and eosin. 
monia" with cough and rusty sputum, fever, and chest pain. By 1954 there was shortness of breath on stairs and the patient moved to a bungalow. Another bout of "pneumonia" with ankle œdema occurred, for which she was admitted to a hospital. On the second day transient aphasia occurred. She was given a six weeks' course of 6 mega units of penicillin for suspected subacute bacterial endocarditis. In 1955 another "chest infection" associated with cardiac failure occurred, which cleared in ten days. Shortly before admission there was an episode of dyspnœa, precipitated by window cleaning. There was no history to suggest rheumatic fever.

On examination, the patient was afebrile and in no distress. The lungs were clinically clear. There was atrial fibrillation with an apical rate of $80 / \mathrm{min}$. The blood pressure was $140 / 90 \mathrm{~mm}$. $\mathrm{Hg}$. The first sound in the mitral area was loud and followed by a soft, blowing systolic murmur. A faint but definite diastolic murmur was heard. The second sound in the pulmonary area was loud and split. The liver was not enlarged and the spleen impalpable. There was no ankle œdema.

On fluoroscopy there was straightening of the left cardiac border. The left atrium was moderately enlarged. The right ventricle was prominent in the right anterior oblique view. The left ventricle was not enlarged. No calcium was seen in the mitral or aortic valve areas. The cardio-thoracic ratio was $13.9 \mathrm{~cm} . / 23.9 \mathrm{~cm} .(59 \%)$.

Electrocardiogram. There was atrial fibrillation, with depression of the S-T segments due to digitalis, and right axis deviation. Lead V1 was not suggestive of right ventricular hypertrophy.

Laboratory Investigations. Urinalysis, normal; Blood: E.S.R., $79 \mathrm{~mm} . / 1 \mathrm{st}$ hour; Hb, 75 per cent; R.B.C., 3,800,000/c.mm.; W.B.C., 6400/c.mm.; W.R., negative; blood cultures, sterile.

Mitral stenosis was diagnosed and commissurotomy advised. Therapy was continued with digitalis and a low sodium diet commenced. For three weeks prior to operation the E.S.R. remained between 52 and $79 \mathrm{~mm} . / 1 \mathrm{st}$ hour, with normal white cell counts and sterile blood cultures. She was afebrile throughout this period.

At operation on $28 / 4 / 55$, under general anæsthesia, a normal mitral valve, with a firm, round tumour arising from the inter-atrial wall, was found. The patient was cooled to $31^{\circ} \mathrm{C}$. by pouring cold saline into the open chest, the chest wall incision was extended trans-sternally, and the tumour removed in three pieces through the incision in the atrial appendage, which had been extended into the atrium. Post-operatively the cardiogram showed normal rhythm, but by the sixth day despite quinidine, atrial fibrillation recurred. Recovery was uneventful and she was discharged on the 23rd post-operative day, in sinus rhythm.

Follow-up. She was well until November, 1956, when a cholecystectomy was performed for gallstones. Quinidine was discontinued eight months after operation. Towards July, 1957, there was decreasing exercise tolerance with episodes of oppressive sensations in the chest and in August there occurred an episode of cardiac arrhythmia, which reverted to sinus rhythm. Serial cardiograms showed myocardial infarction. In February, 1958, a carcinoma of the uterus was irradiated with radium, followed by pan-hysterectomy.

She was reassessed at the Toronto General Hospital in June because a systolic murmur had appeared after the myocardial infarct. Possible recurrence of the tumour was considered. Right heart catheterization showed a pulmonary "wedge" and artery pressure at the upper limit of normal. Angiocardiography showed no filling defect in the left atrium. The phonocardiogram showed an early, short, decrescendo systolic murmur at the apex, heard best in the erect and less well in the left lateral and supine positions. The electrocardiogram showed sinus rhythm. The $\mathbf{P}$ wave was biphasic in VI. There were $\mathbf{T}$ wave changes in keeping with an old myocardial infarct.

Pathology. The tumour weighed $75 \mathrm{~g}$. and measured $8 \times 5 \times 3.5 \mathrm{~cm}$. It was coarsely lobulated and heartshaped. One half was firm, with a pale, brownish-yellow to greyish-white colour, while the other was ragged in parts and smooth in others and extremely friable (Fig. 3).

The histological examination was consistent with the diagnosis of a myxoma (Fig. 4).

Case 3. A woman, aged 57, was admitted to the Toronto General Hospital on in 1958. Six months prior to this she had developed an influenza-like illness lasting two weeks, diagnosed as "pneumonia" and treated with penicillin. Following this she developed left infra-clavicular pain and shortness of breath on exertion. The shortness of breath increased and attacks of nocturnal dyspnoa commenced. These symptoms were not controlled on digitalis and oral diuretics. There was no history suggestive of rheumatic fever.

On examination the patient was afebrile, but orthopnœic and showed a malar flush. The jugular veins were distended. The pulse was regular, 110/min., and the blood pressure $110 / 65 \mathrm{~mm}$. $\mathrm{Hg}$. The apex beat was palpable one $\mathrm{cm}$. outside the mid-clavicular line. The first sound in the mitral area was loud and 


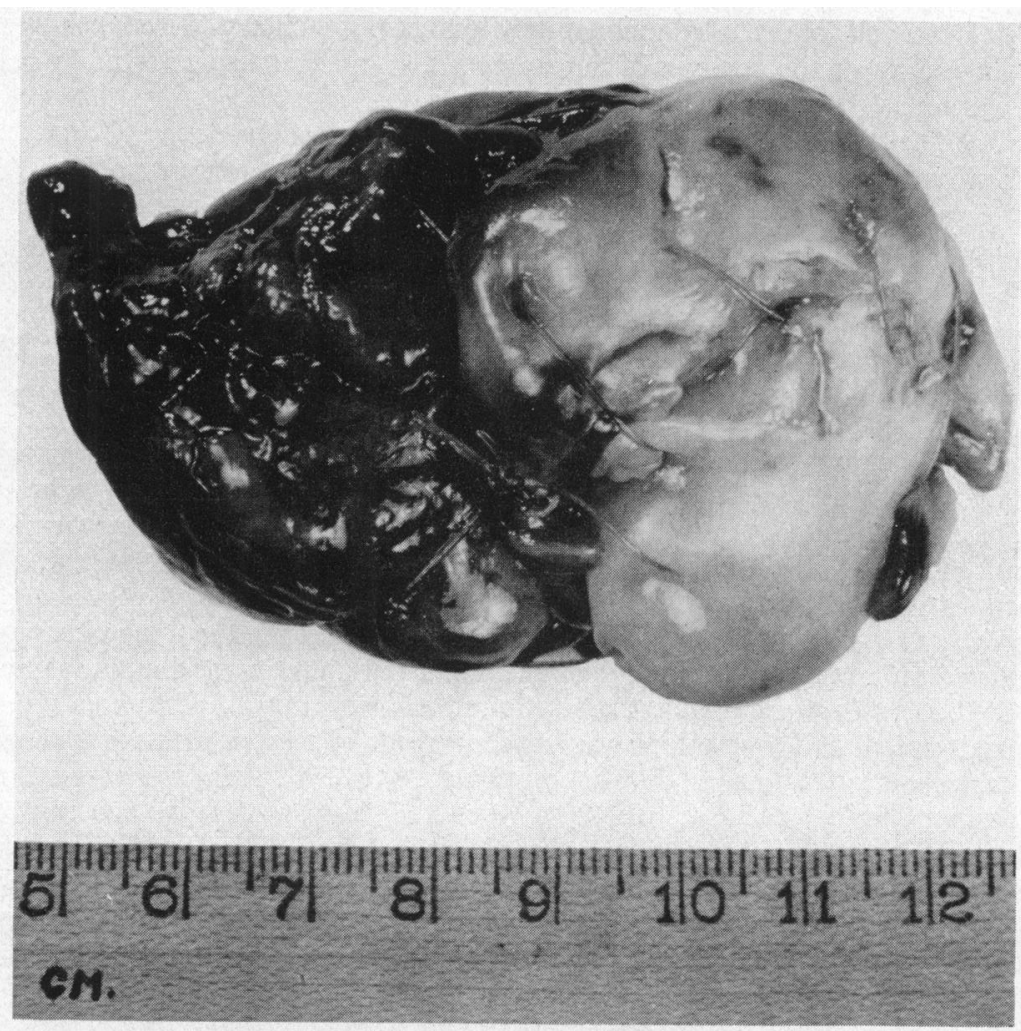

FIG. 3.-Surgical specimen of a myxoma of the left atrium (Case 2).

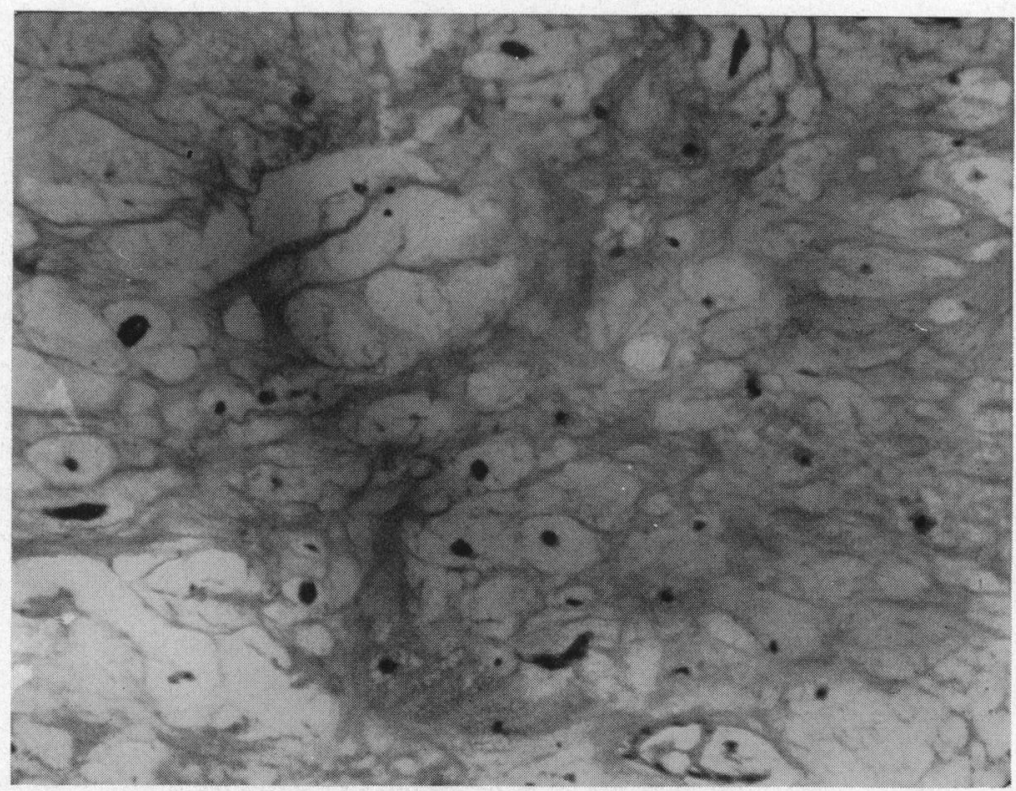

FIG. 4.-Photomicrograph of myxoma (Case 2). Shows many moderately sized vacuolated areas in a relatively acellular eosinophilic staining matrix. There are occasional spindle-shaped cells. A thin-walled capillary blood vessel may be seen in the lower right hand corner. $\times 144$. Hæmatoxylin and eosin. 
preceded by a presystolic and followed by a moderately loud, high-pitched pan-systolic murmur. The latter was more easily audible inside the position of the apex beat. The liver was enlarged three fingers' breadths below the costal margin. There was minimal ankle œdema.

On fluoroscopy the cardiac silhouette was enlarged with straightening of the left cardiac border. The left atrium was moderately enlarged. The right atrium and the ventricles were normal. No calcium was seen in the mitral or aortic valve areas. The cardio-thoracic ratio was $14.6 \mathrm{~cm} . / 23 \cdot 3 \mathrm{~cm} .(63 \%)$.

Electrocardiogram. Sinus rhythm with occasional extrasystoles. The $\mathrm{P}$ waves were widened. There was depression of the $\mathrm{S}-\mathrm{T}$ segments due to digitalis. Right axis deviation was present. Lead $\mathrm{V}_{1}$ was not suggestive of right ventricular hypertrophy.

Laboratory Investigations. Urinalysis, normal; Blood: E.S.R., $17 \mathrm{~mm} . / 1 \mathrm{st}$ hour; Hb, 77 per cent; R.B.C., 4,600,000/c.mm.; W.B.C., 8000/c.mm; non-protein nitrogen, $29 \mathrm{mg}$. per $100 \mathrm{ml}$; protein bound iodine, 5.0 micrograms per $100 \mathrm{ml}$.

Right heart catheterization showed a "wedge" pressure of $25 \mathrm{~mm}$. $\mathrm{Hg}$, pulmonary artery pressure of $87-92 / 32-37 \mathrm{~mm}$. $\mathrm{Hg}$, right ventricular pressure of $85-90 / 0 \mathrm{~mm}$. $\mathrm{Hg}$ and mean right atrial pressure of $7 \mathrm{~mm}$. Hg. There was no gradient across pulmonary or tricuspid valves. There was no evidence of an intracardiac shunt. The cardiac output by the direct Fick principle was 2.34 litres $/ \mathrm{min}$. The pulmonary vascular resistance was 1060 dynes $/ \mathrm{sec} . / \mathrm{cm} .^{-5}$.

Mitral stenosis was diagnosed and commissurotomy advised. During the three weeks prior to operation the patient was placed on a low sodium diet, digitalis, mercurial diuretics, and aminophyllin.

Operation on $25 / 2 / 58$, under general anæsthesia, showed a normal mitral valve and a tumour mass arising from the interatrial wall. The operation was discontinued. Following this rapid atrial fibrillation commenced but was converted to sinus rhythm six days later. On 2/4/58 removal of the tumour was carried out under hypothermia with cardiac arrest for $7 \frac{1}{2}$ minutes. The post-operative course was uneventful.

At a recent out-patient attendance the patient was well and relieved of her cardiac symptoms.

Pathology. The fragments of tumour tissue weighed $28 \mathrm{~g}$. The outer surface was smooth and hæmorrhagic. The cut surface had a variegated red and glassy appearance (Fig. 5). The histology was consistent with the diagnosis of a myxoma (Fig. 6).

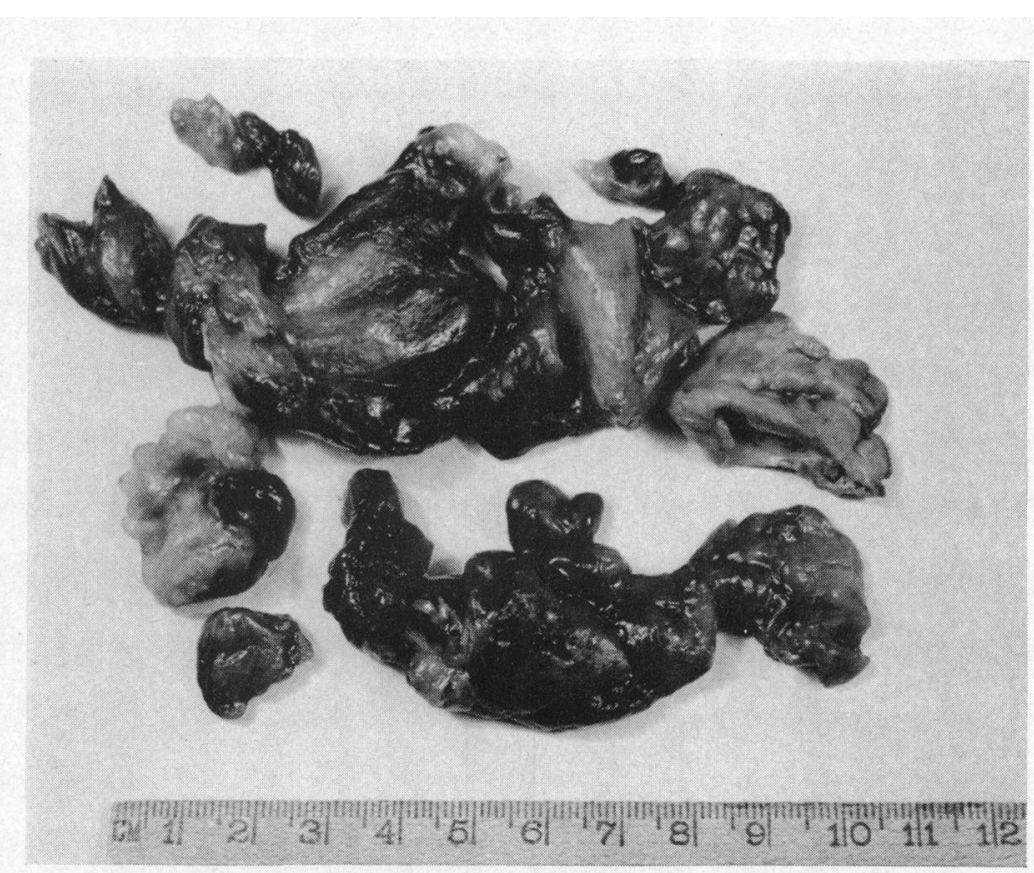

FIG. 5.-Surgical specimen of a myxoma of the left atrium (Case 3). 


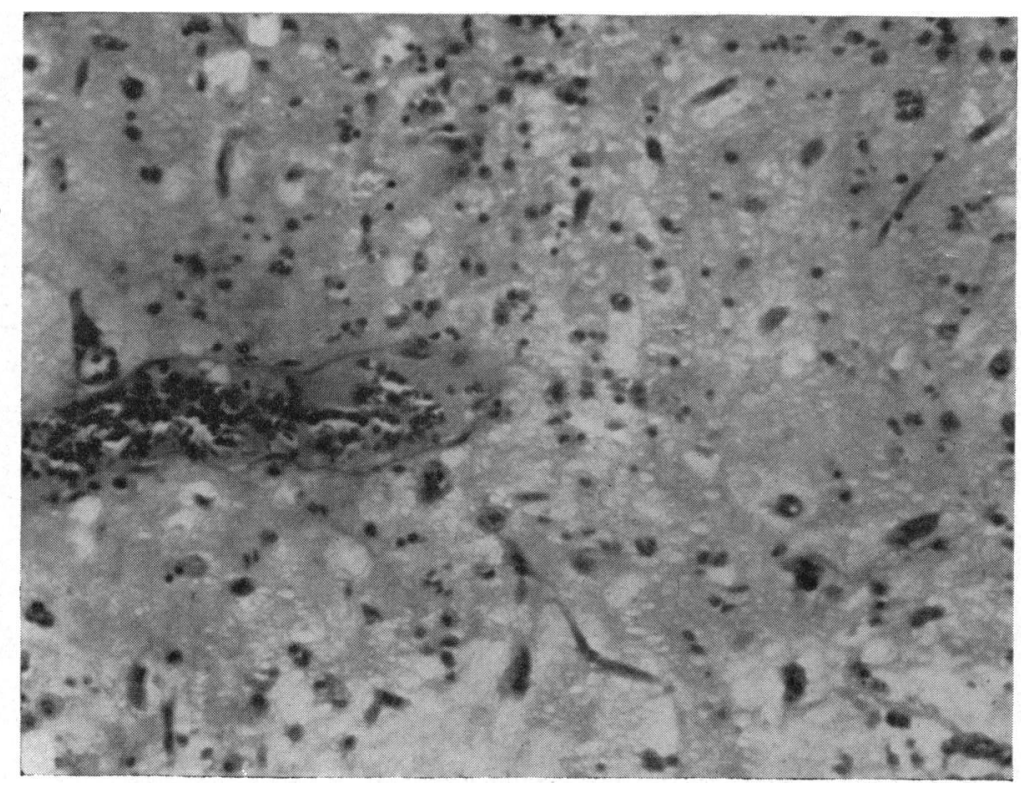

FIG. 6.-Photomicrograph of myxoma (Case 3). Shows a homogeneous eosinophilic staining ground substance containing numerous round and spindle-shaped cells. There is a large thin-walled blood vessel containing numerous red cells. Some red cells may be seen scattered in the ground substance adjacent to the blood vessel. $\times 144$. Hæmatoxylin and eosin.

\section{RESULTS}

The age and sex distribution are shown in Table I. Approximately six out of seven cases occurred between the ages of 30 and 59 and nearly three-quarters of the cases were female. This does not help to distinguish myxoma from mitral stenosis. A case has been reported at three months of age (Pritchard, 1951), but this has not been included in our selection.

TABLE I

Age and Sex Distribution of 35 Cases of Left Atrial Myxoma

\begin{tabular}{ll|c|c|c|c|c|c|c}
\hline & $\begin{array}{c}\text { Years } \\
0-9\end{array}$ & $\begin{array}{c}\text { Years } \\
10-19\end{array}$ & $\begin{array}{c}\text { Years } \\
20-29\end{array}$ & $\begin{array}{c}\text { Years } \\
30-39\end{array}$ & $\begin{array}{c}\text { Years } \\
40-49\end{array}$ & $\begin{array}{c}\text { Years } \\
50-59\end{array}$ & $\begin{array}{c}\text { Years } \\
60 \text { and up }\end{array}$ \\
\hline Male & 9 & 2 & 0 & 1 & 2 & 3 & 1 & 0 \\
\hline Female & 26 & 1 & 1 & 0 & 6 & 7 & 10 & 1 \\
\hline Total & 35 & 3 & 1 & 1 & 8 & 10 & 11 & 1 \\
\hline
\end{tabular}

Patients with a history of rheumatic fever have been found to have a myxoma (Belcher, 1958) and a myxoma and mitral stenosis have been found in the same patient (Marians and Ödman, 1957; Case 1 of this communication). Only about 55-60 per cent of our patients with mitral stenosis have a history of rheumatic fever and a similar figure is quoted by Wood (1956). Thus the presence or absence of a history of rheumatic fever does not help to distinguish myxoma from mitral stenosis. 
The duration of cardiac symptoms could not be determined from the reports in four cases. In 14 of the 31 cases that underwent cardiac surgery the duration of symptoms before operation was three years or less in 10 and four years or more in 4 cases, and in one of these this period was 20 years. Of the 17 cases not subjected to surgery 14 lived only one year after onset of symptoms and only two lived four or more years. Thus, once symptoms commenced the patients did not live very long and remission of symptoms was unusual.

In mitral stenosis, on the other hand, 50 per cent of badly disabled patients will live five years (Wilson and Greenwood, 1954; Oleson, 1955; Robb and Marks, 1953). Wood (1956) and Oleson (1955) state that symptoms exist for seven to fifteen years before total incapacity.

\section{TABLE II}

\section{Manifestations in 35 Cases of Left Atrial Myxoma}

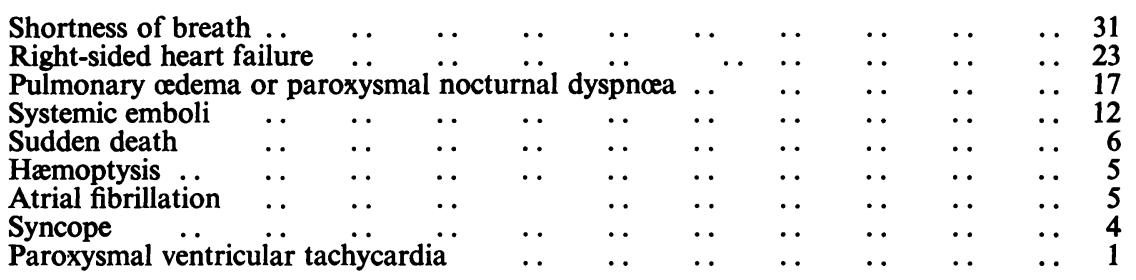

There are no manifestations of mitral stenosis except paralysis of the left recurrent laryngeal nerve (Ortner's syndrome) that do not occur with myxomata. However, syncope is hardly ever encountered in mitral stenosis but this occurred in only 4 cases in this series of 35 myxomata. It was related to a change of posture in the case described by Van Buchem and Eerland (1957), but not in the other three. The case described by Shields (1956) had one attack only, while those of Bahnson et al. (1957) and Von Reis (1949) each had several attacks. Either the obstruction of the mitral orifice, or perhaps of the pulmonary veins, explains this phenomenon. Syncope, when present, is of diagnostic help.

Systemic emboli occurred in nearly one-third of the cases. At autopsy tumour emboli were found. Nearly half the emboli were cerebral. In three cases (Gleason, 1955; Harvey, 1957: Cases 3 and 5), myocardial emboli were found. The diagnosis could presumably be made from histological section if embolectomy were carried out. Sudden death occurred in six cases and was due to either impaction of the tumours in the mitral orifice or sudden irreversible ventricular fibrillation.

Cardiac arrhythmias are uncommon, sinus rhythm being usual. This may be because the tumour remains confined to the endocardium and does not infiltrate the myocardium.

Thirty-four cases showed progressive deterioration in their symptoms. One (Gerbode et al., 1958) had an asymptomatic period of 21 months' duration between the first and final attacks of congestive heart failure. Apart from syncope no intermittence was evident. In fact, progression, despite adequate treatment for failure, was commonly found.

Cardiac Sounds. These were commented on in 27 cases. A loud mitral first and pulmonary second sound was heard in 21 , while in a further three the pulmonary second sound only was loud. Thus, auscultation suggested a raised pulmonary arterial pressure in 24 , and in 8 of these, it was confirmed by right heart catheterization.

An opening snap was heard in two cases (Chin and Ross, 1957; Horlick and Merriman, 1957). In both the mitral valve was normal at operation. A doubtful opening snap was reported in two others.

Cardiac Murmurs. Heart murmurs in patients with myxomata have been said to vary with change in position and from day to day. The diastolic murmur in tight mitral stenosis may be absent or difficult to hear or may be heard only from time to time. It may come and go with changes in 
cardiac function, or it may be heard only after exercise and with the patient lying on his left side. The apical systolic murmur in mitral stenosis is also variable.

Details of heart murmurs were available in 34 of the 35 cases and are shown in Table III. In none of these 34 were there other than mitral murmurs reported. Twenty-five patients had constant diastolic murmurs. Three others had no murmurs (Van Buchem and Eerland, 1957; Shields, 1956; Lekisch, 1957).

TABLE III

Mrtral Murmurs in 34 Cases of Left Atrial Myxoma

\begin{tabular}{l|c|c}
\hline Diastolic & Systolic & Number \\
\hline Constant & - & 6 \\
\hline Constant & Constant & 17 \\
\hline Constant & Inconstant & 2 \\
\hline Inconstant & - & 1 \\
\hline Inconstant & Inconstant & 1 \\
\hline- & Constant & 4 \\
\hline No murmur & No murmur & 3 \\
\hline
\end{tabular}

Blood Pressure. This was reported on in 23 patients and in 18 of these it was under $140 / 90 \mathrm{~mm}$. Hg. It is of no diagnostic help.

Fluoroscopy. Fluoroscopy or X-ray findings are mentioned in only 16 cases. In these there was minimal to moderate left atrial enlargement. Some right ventricular enlargement was present in nine of them. A further five were reported to have enlargement of the pulmonary conus or straightening of the left cardiac border, suggestive of a mitral configuration.

Electrocardiogram. The electrocardiogram was described in 16 cases. In 12 right axis deviation was present and a further 3 were said to show right ventricular hypertrophy. In all of 15 cases the $\mathbf{P}$ waves were described as prominent, broad, or abnormal. Left axis deviation was seen in one case with a blood pressure of $150 / 90 \mathrm{~mm} . \mathrm{Hg}$.

Right Heart Catheterization. This was carried out in eight cases. Six showed pulmonary hypertension with a systolic pressure in the pulmonary artery greater than $70 \mathrm{~mm}$. $\mathrm{Hg}$. The pulmonary "wedge" pressure was raised when measured. Thus the findings are again the same as those of mitral obstruction. Details are shown in Table IV.

Angiocardiography. Angiocardiography was performed in five cases and in each case a filling defect of the left atrium was demonstrated. In one of our recent cases of mitral stenosis, clinically suspected of having a myxoma, angiocardiography, injecting 30 per cent hypaque through a Björk needle into the left atrium, showed a filling defect interpreted as a myxoma. Thus, pictures taken after injection of dye directly into the left atrium were misleading in this case.

Blood Cultures. Blood cultures were taken in 10 cases and were negative. It is not clear from the text whether these were taken because subacute bacterial endocarditis was suspected, or to exclude this complication.

Mode of Death in Cases not Subjected to Operation. There were 19 cases that were not operated on. Sudden death occurred in five of these and was probably due to impaction of the tumour in the mitral valve. However, ventricular fibrillation cannot be excluded. Fourteen cases died in congestive heart failure.

Surgical Treatment. An increasing number of reports of successful removal of myomata have appeared in recent years. Using the extra-corporeal circulation, Crafoord (1955) reported the first 
TABLE IV

Details of Right Heart Catheterization in 8 Left Atrial Myxomata

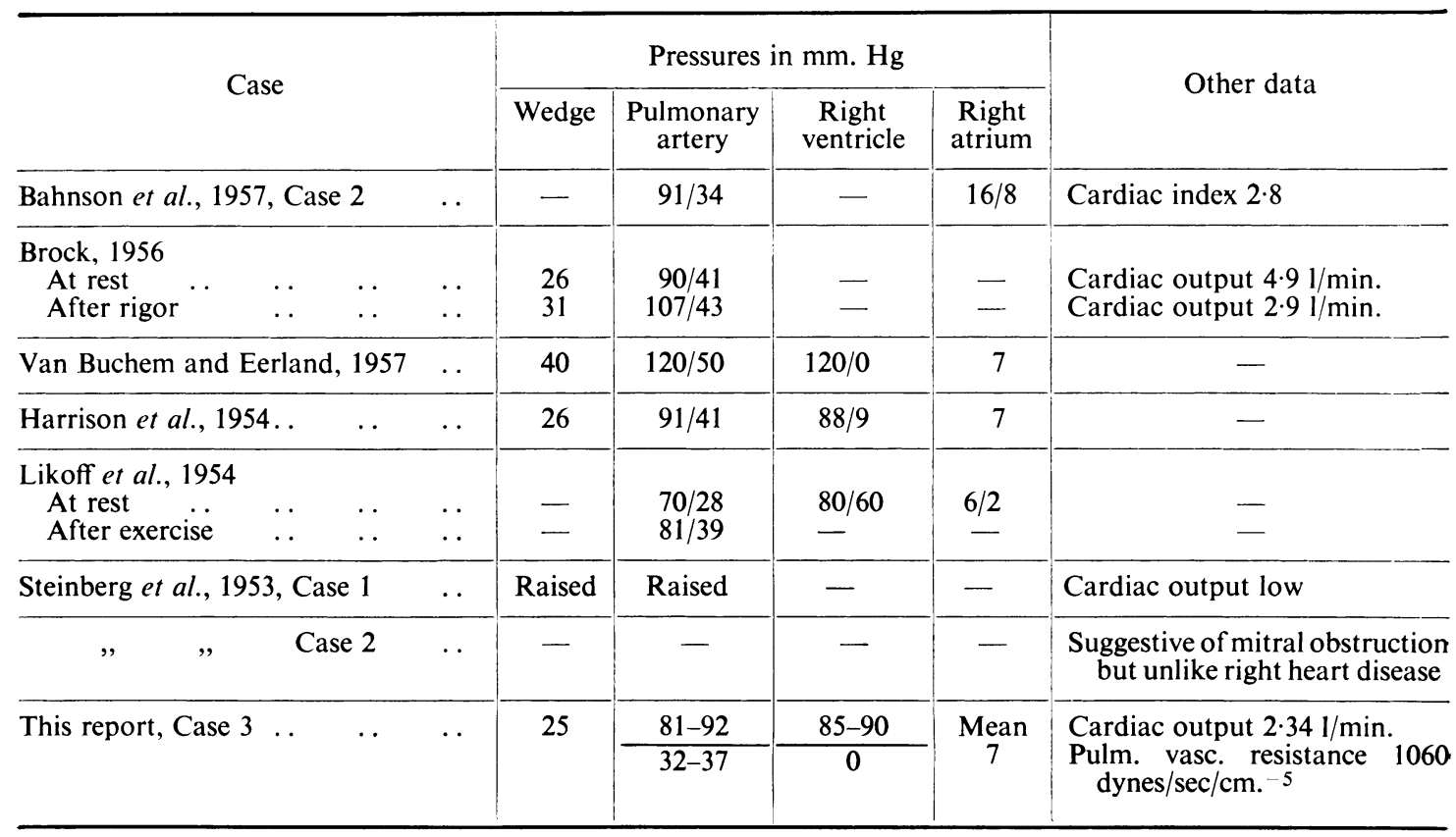

successful case at the International Symposium on Cardiovascular Surgery. Later that same year Bigelow et al. (1955) reported a second (Case 2 of this report) at the 16th Congress of the International Society of Surgery, using hypothermia. Since these reports, other centres have reported successful cases using one of these two methods (Bahnson et al., 1957; Belcher, 1958; Chin and Ross, 1957; Marions and Ödman, 1957; Scannell et al., 1956). Even with the use of these methods, there is some mortality (Bahnson et al., 1957; Brock, 1956; Van Buchem and Eerland 1957). Attempted removal under general anæsthesia has almost always proved fatal (Bahnson et al., 1957; Goldberg et al., 1952; Likoff et al., 1954). Recently Fatti and Reid (1958) reported a case in which at operation for mitral stenosis a myxoma of the left atrium was encountered and successfully removed under general anæsthesia.

If a myxoma is found at operation for mitral stenosis, it seems unwise to attempt removal under general anæsthesia. Hypothermia, modified hypothermia (Case 2 of this report), or the extracorporeal circulation should be used. This may mean postponing removal, and the surgeon's decision when faced with this situation must depend upon the facilities available. In Case 2 of this report modified hypothermia was commenced and removal carried out at once, while in Case 3 removal was postponed and then carried out under hypothermia. The majority of myxomata are friable and fragment with ease (Bahnson et al., Case 2, 1957). Excessive manipulation should be avoided. Brewin (1951) described a case in which the tumour detached spontaneously and impacted in the lower abdominal aorta.

Case 1 of this report illustrates the inadvisability of relieving any associated mitral stenosis without first removing the tumour. Here the tumour impacted in the mitral valve 36 hours after mitral commissurotomy.

The Mitral Valve. Information on this was available in 24 out of 35 cases in this series. Details were obtained at autopsy or operation. One showed moderate mitral stenosis (Case 1 in this report). In 21 cases the mitral valve was normal. In two there was some doubt: one was apparently normal at operation but was incompletely palpated and the other had slight thickening 
and shortening of the chordeæ tendineæ. However, neither of these had any significant degree of stenosis.

\section{Aetiology and Pathology}

There are two prevalent views on the origin of these tumours: first, that they are a true myxomatous neoplasm; second, that they are composed of organizing thrombus undergoing myxomatous degeneration. The site of origin appears to be almost consistently confined to the region of the fossa ovalis, whether the tumour arises in the left or right atrium. According to Ribbert (1924) these myxomata arise from persisting embryonic cell rests. This appears to be the opinion held by most authors. Thorel (1915) after studying the papers on this subject, came to the conclusion that the description of the pathology allowed a diagnosis of organizing thrombus undergoing myxomatous degeneration to be made. Arguments against this view are well set out by Yater (1931). Briefly, both the site of origin, as well as the structure of these tumours, differ from the picture of organizing thrombus. Myxomata are found almost exclusively in the left and right atria, while thrombi occur with equal frequency in atria and ventricles (Ribbert, 1924). As a rule, the heart shows no signs of trauma or endocarditis in myxomata. A thrombus in other locations tends to retract and become effaced. On section a thrombus shows stratification and organization from the periphery inwards.

Eighty per cent of myxomata are polypoid or occasionally villous. The remaining 20 per cent are globular. They are reddish to yellowish-grey in colour, semi-gelatinous and arise from a pedicle at the rim of the fossa ovalis. They may be firm, but are more often soft and extremely friable and tumour emboli are common. Following detachment of tumour and pedicle from the atrial wall, hardly any visible site of attachment may remain.

The histology shows a characteristic substrate of mucoid-staining material, which contains round or stellate cells and varying amounts of connective tissue. There may be some elastic fibres present. Numerous capillary or larger blood vessels are found scattered throughout. Hæmorrhages, as well as deposits of hæmosiderosis, are found. Occasionally marrow, bone and even calcification has been described. The tumour is covered by endothelium. It does not involve the myocardium.

\section{Discussion}

Small myxomatas, which have been asymptomatic, may be found at autopsy. Symptoms do not appear until the myxoma is of such a size as effectively to obstruct the blood flow. Embolization could be an exception to this. As the tumour grows the cavity of the left atrium is increasingly filled. Giant left atria, as sometimes occur in mitral valve disease, are not seen in myxomatas. Perhaps rheumatic disease of the atrial wall is necessary to give rise to a giant left atrium. The lack of atrial disease probably also explains the lower incidence of atrial fibrillation. It seems unfortunate that the left atrium does not enlarge much, because this might allow blood to flow past the obstructing tumour.

Both myxoma and mitral stenosis obstruct the flow of blood from the lungs to the left ventricle. The symptoms and signs produced by them are usually indistinguishable.

Myxomatas are not usually associated with atrial fibrillation. Most patients with myxoma show a downhill course, which is more rapid and unremitting than in mitral stenosis. Syncope caused by mitral stenosis is extremely rare, but about one in ten patients with myxoma has syncope; and when syncope occurs with the symptoms and signs of mitral obstruction, this should suggest a tumour. Emboli are common in both myxoma or mitral stenosis. If an embolectomy is performed and the embolus examined under the microscope the diagnosis could presumably be made. It seems impractical to do routine angiocardiography on all patients with mitral obstruction. In patients with syncope or with a rapid and unremitting downhill course, angiocardiography, injecting dye from the right ventricle or pulmonary artery, should be performed. 


\section{SUMMARY}

Three cases thought to have mitral stenosis were found at operation to have a myxoma of the left atrium. The reports on myxoma of the heart have been extensively reviewed and 32 cases with sufficient clinical details have been selected in addition to these three cases, in order to determine whether it is possible to distinguish between these two conditions by clinical means.

Thus the clinical manifestations in a total of 35 cases have been analysed, as were the electrocardiographic and fluoroscopic findings and right heart catheterization results, where these were available. The operative results and the pathology are briefly discussed. From the analysis it is concluded that differentiation between left atrial myxoma and mitral stenosis is usually impossible. However, when signs of mitral valve obstruction present with a rapid, unremitting downhill course or with syncope, an angiocardiogram should be performed to exclude a myxoma.

\section{REFERENCES}

Bahnson, H. T., Spencer, F. C., and Andrus, E. C. (1957). Ann. Surg., 145, 915.

Belcher, J. R. (1958). Brit. J. Tuberc., 52, 62.

Benjamin, H. S. (1939). Arch. Path., 27, 950.

Bigelow, W. G., Dolan, F. G., and Campbell, F. W. (1955). XVIme Congrés de la Société Internationale de Chirugie, Copenhagen, p. 631.

Block, W. J., Parker, R. L., and Edwards, J. E. (1932). Proc. Mayo Clin., 27, 361.

Brewin, T. B. (1951). Guy's Hosp. Rep., 100, 278.

Brock, Sir Russell (1956). Guy's Hosp. Rep., 105, 382.

Centano, P. A. (1955), Paediatrics, 16, 489.

Chin, E. F., and Ross, D. N. (1957). Brit. med. J., 1, 1447.

Crafoord, C. (1955). Henry Ford Hospital. International Symposium on Cardiovascular Surgery. Edited by C. R. Lain. W. B. Saunders \& Co., Philadelphia, p. 202.

Cropper C. F. J., and Winstanley, D. P. (1955). Brit. med. J., 1, 1513.

Evans, E. (1956). Southern med. J., 49, 979.

Fatti, L., and Reid, F. P. (1958). Brit. med. J., 11, 531.

Gerbode, F., Osborne, J. J., Robson, G. B., Braimbridge, M., and Hultgren, H. (1958). Ann. Surg., $147,321$.

Gleason, I. O. (1955). Cancer, 8, 839.

Goldberg, H. P., Glenn, F., Dotter, C. T., and Steinberg, I. (1952). Circulation, 6, 762.

Gunton, R. W., Paul, W., and Heimbecker, R. O. (1958). Clin. Res. Proc., 6, 218.

Harrison, J. W., McConnack, L. J., and Ernstene, A. C. (1954). Circulation, 10, 766.

Harvey, J. C. (1957). Ann. intern. Med., 47, 6.

Horlick, L., and Merriman, J. E. (1957). Canad. med. Ass. J., 77, 582.

Kroopf, S. S., and Peterson, C. A. (1957). Arch. intern. Med., 100, 819.

Lekisch, K. (1957). Ann. intern. Med., 46, 892.

Likoff, W., Geckeler, G. D., and Gregory, J. E. (1954). Amer. Heart J., 47, 619.

Mahaim, I. (1945). Les Tumeurs et les Polypes du Caur. Masson et cie., Paris.

Marions, O., and Ödman, P. (1957). Acta Radiol., 47, 461.

Maronde, R. F. (1955). Amer. Heart J., 49, 124.

Martin, B. F. (1953). Ann. intern. Med., 38, 325.

Oleson, K. H. (1955). Mitral Stenosis. A Follow-up of 351 Patients. Ejnar Munskgaards Forlag. Copenhagen.

Orr, J. W. (1942). J. Path. Bact., 54, 125.

Pritchard, R. W. (1951). Arch. Path., 51, 98.

Ribbert, H. (1924). Endokardtumor in Henke \& Lubarsch. Handbuch der speziellen Pathologischen Anatomie und Histologie. Berlin, Julius Springer, vol. 2, 276. (Quoted by Yater, 1931).

Robb, G., and Marks, H. (1953). Statistics, by Metropolitan Life Insurance Co.

Scannell, J. G., Brewster, W. R., and Bland, E. F. (1956). New Engl. J. Med., 254, 601.

Shields, J. P. (1956). J. Indiana State Med. Assoc., 49, 167.

Steinberg, J., Dotter, C. T., and Glenn, F. (1953). Dis. Chest, 24, 509.

Thorel, C. (1915). Ergeb. allg. Path. path. Anat., 17 (pt. 2): 667. (Quoted by Pritchard, 1951).

Van Buchem, F, S. P., and Eerland, L. D. (1957). Dis. Chest, 31, 61.'

Von Reis, G. (1949). Acta med. Scand., 133, 214.

Wilson, J. K., and Greenwood, W. F. (1954). Canad. med. Ass. J., 71, 323.

Wood, P. (1956). Diseases of the Heart and Circulation. 2nd edition. Eyre \& Spottiswood, London.

Yater, W. M. (1931). Arch. intern. Med., 48, 187.

Young, R. D., and Hunter, W. C. (1947). Arch. Path., 43, 86.

Case Records of the Massachusetts' General Hospital (1957). New Engl. J. Med., 256, 516. 